\title{
Antimicrobial activity of Origanum vulgare essential oil (Oregano) and its compound isolated against cells of Streptococcus spp., Candida spp. and Staphylococcus aureus MRSA.
}

\section{Natalia Kaori Aida*, Janaina P. Barbosa, Thaís R. de Oliveira, Vanessa S. Cardoso, José F. Höfling.}

\begin{abstract}
Oreganum vulgare essential oil and its isolated compound carvacrol have antimicrobial effects demonstrated in the literature as antibacterial and antifungal activity. The objective of this work was to evaluate the antifungal activity of essential oil and compound against standard strains of Candida spp., Streptococcus spp. and Staphylococcus aureus Methicillin resistant by the M27-A3 broth microdilution method (CLSI, 2008) in the determination of MIC and CFM. Commercial antifungal Fluconazole and Chlorhexidine were used as susceptibility parameters.
\end{abstract}

\section{Key words: \\ Oreganum vulgare, Carvacrol, Medicinal plants.}

\section{Introduction}

The use of plants as an alternative to medicinal treatments is an ancient practice. Studies on medicinal plants have become increasingly relevant, and ethnobotanical and ethno-pharmacological knowledge is considered essential for the development of new drugs. Several plants have been tested in order to find active biocomposites that can be used in the development of new drugs ${ }^{1}$, since microbial resistance has brought great problems in the treatment of infectious diseases and the development of new agents antimicrobial agents ${ }^{2}$. The present study aimed to study the antimicrobial activity of Origanum vulgare essential oil and its isolated Carvacrol compound against Candida, Streptococcus and Staphylococcus microorganisms.

\section{Results and Discussion}

The antifungal and antibacterial activities of $O$. vulgare essential oil and its isolated compound Carvacrol were tested by the Broth Microdilution technique (CLSI, 2008) and Gullo (2012). The essential oil of $O$. vulgare demonstrated inhibitory activity for the genus Candida, Streptococcus and for the strain of Staphylococcus aureus at concentrations between 0.5 and $0.125 \mathrm{mg} / \mathrm{ml}$; while carvacrol varied in concentrations between 0.250 and $0.0625 \mathrm{mg} / \mathrm{ml}$. The fungicidal and bactericidal activities expressed concentrations of 0.5 and $0.250 \mathrm{mg} / \mathrm{ml}$ for the essential oil and 0.250 to $0.125 \mathrm{mg} / \mathrm{ml}$ for the compound. These data initially demonstrate the antimicrobial action of this essential oil, as well as its isolated compound, corroborating the literature, pointing out that they have antimicrobial activity, exhibiting action against these microorganisms in different ways and can be used to treat resistant infections and/or act as adjuvants.
Chart 1. Results of visual reading of MIC and CFM/CBM of the strains tested.

\begin{tabular}{|l|c|c|c|c|c|}
\hline \multirow{2}{*}{ Reference strain } & \multicolumn{2}{|c|}{ O. vulgare } & \multicolumn{2}{c|}{ Carvacrol } & Fluconazole / \\
\cline { 2 - 6 } & $\mathrm{MIC}$ & $\mathrm{MFC}$ & $\mathrm{MIC}$ & $\mathrm{MFC}$ & Chlorhexidine \\
\cline { 2 - 6 } & $\mathrm{mg} / \mathrm{mL}$ & $\mathrm{mg} / \mathrm{mL}$ & $\mathrm{mg} / \mathrm{mL}$ & $\mathrm{mg} / \mathrm{mL}$ & $\mu \mathrm{g} / \mathrm{mL}$ \\
\hline C. albicans & 0,250 & 0,5 & 0,125 & 0,250 & 1 \\
\hline C. dubliniensis & 0,125 & 0,5 & 0,0625 & 0,250 & 1 \\
\hline C. glabrata & 0,125 & 0,5 & 0,0625 & 0,250 & 1 \\
\hline C. parapsilosis & 0,125 & 0,250 & 0,0625 & 0,250 & 2 \\
\hline C. krusei & 0,250 & 0,5 & 0,125 & 0,250 & 32 \\
\hline C. guilliermondii & 0,125 & 0,250 & 0,0625 & 0,250 & 1 \\
\hline S. mutans & 0,5 & 0,5 & 0,250 & 0,5 & 3,75 \\
\hline S. mitis & 0,250 & 0,250 & 0,125 & 0,125 & 3,75 \\
\hline S. oralis & 0,5 & 0,5 & 0,250 & 0,250 & 15 \\
\hline S. gordonii & 0,250 & 0,250 & 0,125 & 0,125 & 7,5 \\
\hline S. salivarius & 0,250 & 0,5 & 0,250 & 0,250 & 3,75 \\
\hline S. sanguinis & 0,250 & 0,5 & 0,250 & 0,250 & 7,5 \\
\hline S aureus MRSA & 0,5 & 0,5 & 0,250 & 0,5 & \\
\hline
\end{tabular}

\section{Conclusions}

Oreganum vulgare essential oil and isolated compound Carvacrol are biologically active in a dose dependent manner against the species tested in their planktonic form.

\section{Acknowledgement}

CNPq and Piracicaba School of Dentistry/UNICAMP

\footnotetext{
${ }^{1}$ Amjad MS, Qaeem MF, Ahmad I, Khan SU, Chaudhari SK, Malik NZ, Shaheen H, Khan AM. Descriptive study of plant resources in the context of the ethnomedicinal relevance of indigenous flora: A case study from Toli Peer National Park, Azad Jammu and Kashmir, Pakistan. PLoS One. 2017; 12(2) e0171896.

${ }^{2}$ Ayaz M, Ullah F, Sadiq A, Ullah F, Ovais M, Ahmed J, Devkota HP Synergistic interactions of phytochemicals with antimicrobial agents: Potential strategy to counteract drug resistance. Chem Biol Interact. 2019 May 31;308:294-303

${ }^{3}$ CLSI. Método de referência para testes de diluição em caldo para a determinação da sensibilidade de leveduras a terapia antifúngica. Clinical and laboratorial standards institute. CLSI Norma M27-A3. 2008 v.28, n.14, 2 ed.

${ }^{4}$ Gullo FP, Sardi JCO, Santos VAFFM, Sangalli-Leite F, Pitangui NS, Rossi SA, de Paula e Silva ACA, et al. Antifungal activity of Maytenin and Pristimerin. Hindawi Publishing Corporation, 2012.
} 